\title{
Idea and practice of inclusive farming
}

\author{
Winfried Schäfer \\ Natural Resources Institute Finland (Luke), P.O. Box 2, 00791 Helsinki,winfried.schafer@luke.fi
}

\begin{abstract}
Inclusive farming (INCLUFAR) - Transfer of concepts, experiences, skills, and training tools for social farming and eco-social inclusion is an innovation transfer project within the Lifelong Learning Leonardo da Vinci funding scheme of the EU. The results were gathered during the project period from October 2013 until September 2015.

Why INCLUFAR? First, Finland signed the UN convention on the rights of persons with disabilities and is presently adjusting the legislation accordingly. Second, the results of the public consultation on the review of the EU-policy on organic agriculture conducted by the directorate general for agriculture and rural development in 2013 shows that economic and social dimension have the highest priority. Third, social farming and green care enterprises put the multifunctionality demand of policy makers into practice.

Because green care enterprises emerged in the past decade rapidly, there is a lack of qualified staff specialised on both agriculture and social work related professions. The results of the past EU funded green care projects SoFar, DIANA, MAIE, and others reflect this fact addressing development of appropriate VET curricula as a concern.

INCLUFAR meets the need for appropriate curricula suitable for social farming and green care enterprises which link care for both, individuals with special needs and for nature in organic farms. INCLUFAR transferred a new on-farm developed curriculum and the gathered experiences with it to green care enterprises and to related institutions following the principal of inclusion. As a result better labour opportunities emerge, fostering rural economic development. Exploiting the specific agricultural work and life-setting may improve social welfare structure in rural areas.

Outcomes of the project are: 1. The INCLUFAR handbook, providing background knowledge of and concepts for inclusive farming. 2. The INCLUFAR curriculum, available in all partner country languages. 3. An occupational profile to meet the practical steps implementing the INCLUFAR idea.

The skills gathered in the partner countries through coaching team visits to Austria, Bulgaria, Estonia, Finland, Norway, the Netherlands, and Turkey contributed to improve the quality of work on farm as well as on the rural area and its different professions (farmers, gardeners, handicrafts, nurses, social workers, civil servants, students, scientists, decision makers of public authorities, etc.). The term inclusion, as a central concern in the UN convention on the rights of persons with disabilities was also applied to improve the cultural landscape and its biotopes. Thus, the project contributed to improve and support the training path aims of creating a greater awareness of social and ecological inclusion.
\end{abstract}

\section{Keywords}

Inclusion, organic farming, green care, vocational training

The author gratefully acknowledges the substantial contributions of the INCLUFAR-project partners Hartwig Ehlers, Dr. Gerhard Herz, Dr. Thomas van Elsen, and Klaus Merckens to this paper.

This project has been funded with support from the European Commission. This publication reflects the views only of the author, and the Commission cannot be held responsible for any use which may be made of the information contained therein. 


\section{Introduction}

Inclusive farming is implemented by agricultural and horticultural enterprises which integrate people with physical, mental or emotional disabilities, the socially disadvantaged, young offenders, children with learning disabilities, addicts, the long-term unemployed, active seniors, schools and kindergartens. Inclusive farming embraces provision, inclusion, rehabilitation training and a better quality of life.

The first reason for inclusive farming is the UN Convention on the Rights of Persons with Disabilities (United Nations 2006). Finland signed the convention and is presently adjusting the legislation accordingly. This convention is also a result of pioneers working with handicapped people with a strong ethical commitment: Since the seventies of the 19th century several generations of the von Bodelschwingh family managed the Bethel Institution which offers health care and other advantages to the socially disadvantaged. The philosopher and nuclear physics scientist Carl Friedrich von Weizsäcker explains the necessity of inclusion in his essay about Friedrich von Bodelschwingh: „The political world does not bear the sight of suffering. Either she ignores it or she tries to eliminate it. The first alternative is not allowed and the second one is not possible. The Bodelschwinghs had the power to ease suffering, because they considered suffering as a central fact of live and because they were able to look into the eyes of the suffering in brotherliness. Justice without compassion is uncharitable, compassion without justice is dishonouring. The society needs people with special needs because it is lethal for the soul to close the eyes in front of the reality of suffering“. Nobel Peace Prize laureate, theologian, organist, philosopher, physician, and medical doctor in Africa Albert Schweitzer created the idea of "Reverence for Life" and transferred it into practice as farmer and medical doctor in the Lambaréné hospital, now in Gabon. The green care entrepreneur, farmer and teacher Hartwig Ehlers states: "The main difference between people without and with special need is that the latter ones lack the ability to set up their own living environment and to shape their own CV. Thus the challenge of inclusion is to create such an environment that handicapped people can not only live within such an environment but even take it up as their own". Figure 1 illustrates these ethical approaches:

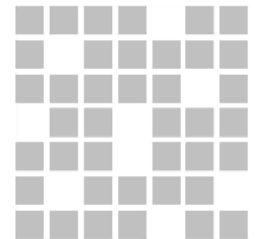

Exclusion

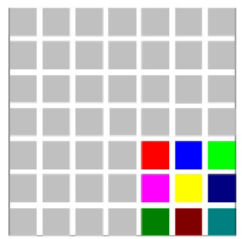

Integration

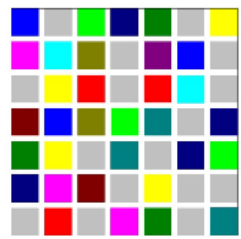

Inclusion

Figure 1: The principle of inclusion

The second reason bases on research results of medical and social sciences. There are numerous approaches to measure the influence of nature upon health and wellbeing (salutogenesis): General SelfEfficacy Scale (GSE) (Bandura 1986; Schwarzer 1992; Schwarzer and Jerusalem 1995; Scholz et al. 2002; Sempik 2007; Berget et al. 2008; Sempik et al. 2010; Pedersen et al. 2011), the WarwickEdinburgh Mental Well-being Scale (WEMWBS) (Tennant et al. 2007; Parkinson 2007; Stewart-Brown et al. 2009), the Sense of Coherence (Antonovsky 1979; Lundberg and Peck 1995; Eriksson and Lindström 2006), the Connor-Davidson Resilience Scale (Connor and Davidson 2003; Vaishnavi et al. 2007 ; Ewert and Yoshino 2011), the Environmental Identity Scale (Clayton 2003; Olivos and Aragones 2011; Cervinka et al. 2012) as well as Satisfaction / Happiness (Campbell et al. 1976; Diener 1984; Waldron, 2010; Dolan et al. 2011) in detail reviewed by Leck (2013).

The third reason is that many European citizens consider the economic and social dimension of organic farming as most needed area of research and innovation in the organic food and farming sector. $58 \%$ of the replies or 26165 persons expressed this opinion in the public consultation on the review of the EU policy on organic agriculture conducted by the directorate general for agriculture and rural development (European Commission 2013). 


\section{Methodology}

Within the INCLUFAR-project several green care entrepreneurs, applying since decade's inclusive farming, exchanged and transferred concepts, experiences, skills, and training tools for social farming and ecosocial inclusion including stakeholders and beneficiaries. They were supported by several academic institutions (MTT/Luke, Petrarca, Akdeniz University), and merckens development support as project manager. The Leonardo da Vinci website (ADAM 2013) and the project website (Hofgemeinschaft WeideHardebek 2013) provide further information.

Table 1: Inclusive farming enterprises of the INCLUFAR-project

\section{Inclusive farming enterprises}

Arbeitsgemeinschaft für anthroposophisches Heilwesen

e.V. -Integrative Hofgemeinschaft Loidholdhof

Hofgemeinschaft Weide-Hardebek LBF gGmbH

Pahkla camphilli Küla

Sylvia Koti association. Tapolan Kyläyhteisö

Urtica de Vijfsprong
Country

$\begin{array}{ll}\text { Austria (AT) } & \text { www.loidholdhof.org } \\ \text { Germany (DE) } & \text { www.weide-hardebek.de } \\ \text { Estonia (EE) } & \text { www.pahklack.org } \\ \text { Finland (FI) } & \text { www.tapola-camphill.fi } \\ \text { The Netherlands (NL) } & \text { www.urticadevijfsprong.nl }\end{array}$

\section{Description of the inclusive farming enterprises}

Austria (AT): The Loidholdhof is a green care provider based on a community of people of which many have physical and mental disabilities. Over 40 people both with and without disabilities have made their home on this farm where they live and work together. As a model for inclusive life-sharing, Loidholdhof gives meaningful impulses for the qualitative and structural further development of work with people with special needs far beyond the surrounding region.

Germany (DE): Weide-Hardebek is a social care provider based on a farm community. It started 40 years ago. Today 54 people with mental disability, psychiatric diseases and milieu-aggrieved people, live and work at Weide-Hardebek. The practical experience has led to the development and implementation of a curriculum and training program that integrates social farming and inclusion. Weide-Hardebek is a recognised in service training provider and the public authorities approved the curriculum and the examination rules.

Estonia (EE): In Pahkla Camphilli Küla live and work 17 people with special needs, 6 co-workers and 2 volunteers. They live together in five family houses and work together in household, farm and workshops. The people with special needs get different therapies and help. As part of the world wide Camphill movement Pahkla practice social farming since years. The objective to initiate a further training program focusing on social farming and inclusion is one of the priorities of Pahkla. The specific competence of Pahkla and its key staff is inclusion and social farming.

Finland (FI): Tapola is a social care provider based on a farm community. Presently about 100 people of which 43 with mental disability, psychiatric diseases and milieu aggrieved people, live and work at Tapola. The organic farm was from the beginning an important working sector. Additionally there are working possibilities in the weaving, creamery and herb workshop as well as in the garden and all houses. Tapola is recognized by Finnish authorities providing social care. Tapola is member of the international network "Camphill Northern Region Association (CNRA)". The practical experience has led to the development and implementation of curricula and quality management procedures transferred within the Baltic Seminar in service training programme.

The Netherlands (NL): Urtica De Vijfsprong is a living and working community with a therapeutic aim located at the eastern part of the Netherlands. Its centre is the bio-dynamic farm De Vijfsprong, named after a junction of 5 sandy roads. For people coming for a shorter or longer period to the farm, this junction often symbolises a new phase in their life. The milk is processed on the farm. The farm products are delivered to customers in the region and the farm has also its own health food shop. Urtica is focusing since years on new training and further education projects to improve professional skill levels of its own employees and at the same time to exchange experience with other similar projects across the Netherlands and Europe. 


\section{The transfer methodology}

Based on the experiences of the partner farms the concept of inclusion concerning people with special needs was applied in the transfer workshops. Thus the transfer workshop delivered orientation how to deal with the new challenges. The concept of sustainability referred to the regional resources and also to the linked regional development of the rural area. The process provided the basis for further initiatives on regional and national level. The transfer method included an internal and external evaluation.

\section{The evaluation process}

The team coaching coordinator sent every host (partner organisation to be coached) some weeks before the venue a partner description form (Schäfer \& Merckens 2015). By this form the host presented his organisation and the present situation of his country concerning inclusive work and possibilities to implement the INCLUFAR curriculum. The partner description form bases on the "Path to Quality" approach which supports the development and the quality management of enterprises and organisations. "Path to Quality" is an accredited quality evaluation system described by Stiftung Wege zur Qualität (2006) following twelve quality management dimensions. The quality management of the enterprises evaluated by this approach may become subject of certification on demand.

\section{Results and discussion}

\section{Type and structure of partner enterprises}

All partner enterprises are nongovernmental organisations and either non-profit organisations or nonprofit associations. Both, regulations of public authorities and public funding scheme determine the appropriate enterprise structure, minimum qualification of staff and supervision in each partner country. Enterprises of the CNRA prefer foundations and/or combinations of foundations and associations. Additionally they follow up the social care provider Camphill Village Trust of Norway principles (Det Kogelige Helse- og Omsorgsdepartment 2013).

The farms offer both working places to create income and food self-sufficiency. In Estonia the farm is the main source of income. Table 1 shows the high diversity regarding land use and animal husbandry. All partner farms lay special emphasis on manifold animal husbandry. This is a precondition for a wide scope of working places showed in table 2 ranging from simple hand work up to working places requiring a university degree. Table 3 shows the services offered to people with special needs and customers.

\section{Evaluation results}

There were altogether twelve fields with five to eight questions per field discussed and evaluated during the transfer workshops. The classification of the answers "yes", "no", "not applicable or not available", "to a certain extent, somehow" was counted and grouped. Questions answered with "yes" (y) indicate implementation of quality and inclusion. Questions answered with "no" (n) indicate issues which have to be implemented to improve inclusion and quality. Questions answered with "to a certain extent, somehow" (o) indicate that inclusion and quality are under construction. Questions answered with not applicable (n/a) indicate that either implementation of the subject is not yet realised or not applicable.

Evaluation of the transfer workshop results base on the answers given to 67 questions of the partner description form. The maximum score of each group was set to 100 and the number of related answers calculated as percentage of the maximum. Figure 2 shows the scores plotted against each other.

The graph confirms that the partners in Austria, Finland, and The Netherlands have a high level of quality and social inclusion. In Estonia the answers to many questions are under construction and many issues wait for implementation. This work is supported by CNRA in Norway. Since 2008 Camphill foundation in Norway has a work description by state authorities and a budget within the national finances (Det Kogelige Helse- og Omsorgsdepartment 2013). 
Table 1: Diversity of agriculture and landscape

\begin{tabular}{|l|c|c|c|c|c|c|}
\hline & Country & AT & DE & EE & FI & NL \\
\hline \multicolumn{5}{|c|}{ Farm description } \\
\hline Farm size, ha & 20 & 190 & 112 & $\begin{array}{c}53+49 \\
\text { forest }\end{array}$ & 44 \\
\hline Staff & 23 & 64 & 10 & 60 & 68 \\
\hline Clients & 24 & 55 & 19 & 48 & 46 \\
\hline
\end{tabular}

\section{Diversity of agriculture and landscape}

\begin{tabular}{|c|c|c|c|c|c|}
\hline forest & $\mathrm{x}$ & & & $\mathrm{x}$ & \\
\hline meadows, pasture & $\mathrm{x}$ & $\mathrm{x}$ & $\mathrm{x}$ & $\mathrm{x}$ & $\mathrm{x}$ \\
\hline park/nature conservation & & $\mathrm{x}$ & & & \\
\hline arable land & $\mathrm{x}$ & $\mathrm{x}$ & $\mathrm{x}$ & $\mathrm{x}$ & \\
\hline horticulture & $\mathrm{x}$ & $\mathrm{x}$ & & $\mathrm{x}$ & $\mathrm{x}$ \\
\hline herbs & $\mathrm{x}$ & $\mathrm{x}$ & & $\mathrm{x}$ & \\
\hline fruits & $\mathrm{x}$ & $\mathrm{x}$ & & $\mathrm{x}$ & \\
\hline berries & $\mathrm{x}$ & $\mathrm{x}$ & & $\mathrm{x}$ & \\
\hline \multicolumn{6}{|c|}{ Animal husbandry } \\
\hline horses & $\mathrm{x}$ & & & & \\
\hline cows & $\mathrm{x}$ & $\mathrm{x}$ & $\mathrm{x}$ & $\mathrm{x}$ & $\mathrm{x}$ \\
\hline donkey & $\mathrm{x}$ & $\mathrm{x}$ & & & \\
\hline sheep & $\mathrm{x}$ & & & $\mathrm{x}$ & \\
\hline pigs & & $\mathrm{x}$ & $\mathrm{x}$ & $\mathrm{x}$ & \\
\hline goats & $\mathrm{x}$ & & & & \\
\hline \multicolumn{6}{|l|}{\begin{tabular}{|l|} 
turkey \\
\end{tabular}} \\
\hline ducks & & $\mathrm{x}$ & $\mathrm{x}$ & & \\
\hline geese & $\mathrm{x}$ & $\mathrm{x}$ & & & \\
\hline chicken & $\mathrm{x}$ & $\mathrm{x}$ & $\mathrm{x}$ & $\mathrm{x}$ & \\
\hline bee keeping & $\mathrm{x}$ & & & $\mathrm{x}$ & \\
\hline
\end{tabular}

Table 2: Inclusive working places and energy

\begin{tabular}{|c|c|c|c|c|c|}
\hline Country & AT & $\mathbf{D E}$ & $\mathbf{E E}$ & FI & NL \\
\hline \multicolumn{6}{|c|}{ Farm production } \\
\hline forestry & $\mathrm{x}$ & & & $\mathrm{x}$ & \\
\hline agriculture & $\mathrm{X}$ & $\mathrm{x}$ & $\mathrm{X}$ & $\mathrm{x}$ & $\mathrm{x}$ \\
\hline horticulture & $\mathrm{X}$ & $\mathrm{x}$ & & $\mathrm{x}$ & $\mathrm{x}$ \\
\hline \multicolumn{6}{|c|}{ Food processing } \\
\hline herb workshop & & & & $\mathrm{x}$ & \\
\hline dairy/cheese & & & $\mathrm{x}$ & $\mathrm{x}$ & $\mathrm{x}$ \\
\hline other food processing & & $\mathrm{x}$ & $\mathrm{x}$ & $\mathrm{x}$ & \\
\hline \multicolumn{6}{|l|}{ Craft } \\
\hline bakery & $\mathrm{X}$ & $\mathrm{X}$ & & $\mathrm{x}$ & \\
\hline weaving/felt/wool workshop & $\mathrm{x}$ & & $\mathrm{x}$ & $\mathrm{x}$ & $\mathrm{x}$ \\
\hline pottery & & & & $\mathrm{x}$ & \\
\hline joinery, carpentry & $\mathrm{x}$ & $\mathrm{x}$ & & & \\
\hline candles workshop & $\mathrm{x}$ & & & & \\
\hline packaging & & $\mathrm{X}$ & & $\mathrm{x}$ & \\
\hline housekeeping & $\mathrm{x}$ & $\mathrm{x}$ & & $\mathrm{x}$ & $\mathrm{x}$ \\
\hline laundry & $\mathrm{X}$ & & & & \\
\hline catering, café, restaurant & $\mathrm{x}$ & $\mathrm{x}$ & & $\mathrm{x}$ & $\mathrm{x}$ \\
\hline administration services & & $\mathrm{x}$ & & & \\
\hline whole sale & & $\mathrm{X}$ & & $\mathrm{x}$ & $\mathrm{x}$ \\
\hline marketing & & $\mathrm{x}$ & & & \\
\hline shop & $\mathrm{X}$ & $\mathrm{x}$ & & $\mathrm{x}$ & $\mathrm{x}$ \\
\hline \multicolumn{6}{|c|}{ Renewable energy } \\
\hline CHP power plant & & $\mathrm{X}$ & & & \\
\hline wood chip furnace & & $\mathrm{x}$ & & $\mathrm{x}$ & \\
\hline heating/fire wood workshop & $\mathrm{x}$ & & & $\mathrm{x}$ & $\mathrm{x}$ \\
\hline
\end{tabular}

Table 3: Range of services of partner enterprises

\begin{tabular}{|l|c|c|c|c|c|l|c|c|c|c|c|}
\hline \multicolumn{1}{|c|}{ Country } & AT & DE & EE & FI & NL & Country & AT & DE & EE & FI & NL \\
\hline Sheltered work & $\mathrm{x}$ & $\mathrm{x}$ & $\mathrm{x}$ & $\mathrm{x}$ & $\mathrm{x}$ & Artistic and cultural work & $\mathrm{x}$ & $\mathrm{x}$ & & $\mathrm{x}$ & \\
\hline Housing & $\mathrm{x}$ & $\mathrm{x}$ & $\mathrm{x}$ & $\mathrm{x}$ & $\mathrm{x}$ & Therapeutic services & $\mathrm{x}$ & & & $\mathrm{x}$ & \\
\hline Nursing home for elderly & & & & $\mathrm{x}$ & & Living assistance & $\mathrm{x}$ & & & & \\
\hline In service training & & $\mathrm{x}$ & & $\mathrm{x}$ & $\mathrm{x}$ & Journal & $\mathrm{x}$ & & & $\mathrm{x}$ & \\
\hline
\end{tabular}

\section{Conclusions}

Inclusive farming is a step towards social and ecological inclusion. It has an impact on the quality of work on a farm as well as on the rural area and its various professions (farmers, gardeners, craftsmen, nurses, social workers, civil servants, etc.). The term "inclusion", as a central concern of the UN Convention on the Rights of Persons with Disabilities, is also applied to improve the cultural landscape and its biotopes. Inclusive farming creates a greater awareness of social and ecological inclusion:

- The eco-social inclusion of the project partner enterprises is well developed.

- The farms are working sustainably: nutrient recycling (self-sufficiency in phosphorus), use of renewable energy, number and quality of working places and the inclusion of landscape (biodiversity) fulfil the targets of related authorities to develop the countryside sustainably.

- "Ways to quality" evaluation-methodology is a useful tool to find out areas to be developed to improve work, inclusion and quality of both.

- Green care enterprises are an excellent research platform for interdisciplinary research themes ranging from agricultural engineering to medical sciences.

- The social return on investment of Green care farms is positive and these pioneer farms show authorities alternative solutions to implement inclusion into practice. The partner farms implemented 
the UN convention on the rights of persons with disabilities sustainably and economically.

- Near all issues addressed by objectives of sustainable agriculture policies are covered by the partner farms working organically for decades, near all these farms employ renewable energy production techniques, solved the phosphorus problem and employ the criteria of sustainable agriculture developed within the EU concerted action AIR5-CT95-1210: Checklist for sustainable Landscape Management (Mansvelt \& Lubbe 1999).

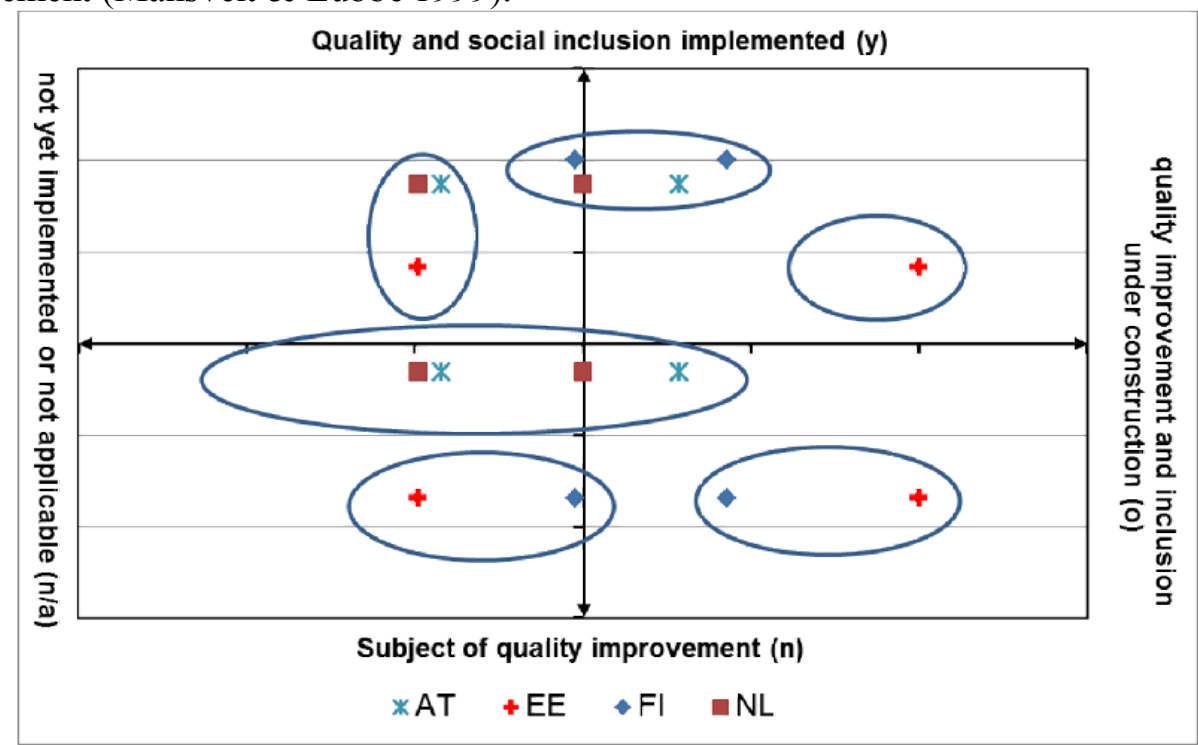

Figure 2: Evaluation of the transfer workshop results based on the answers given to the questions of the partner description form. AT $=$ Austria, EE $=$ Estonia, FI $=$ Finland, NL $=$ The Netherlands.

\section{References}

ADAM, 2013. Projects and products portal for Leonardo da Vinci. Accessed 1.12.2015: http://www.adameurope.eu/adam/project/view.htm?prj=10805\&page=1\#.VmAy_nYrJpg

Antonovsky, A. 1979. Health, stress and coping. San Francisco: Jossey-Bass.

Berget, B., Lidfors, L, Pálsdóttir, A., Soini, K., \& Thodberg, K. 2012. Green Care in the Nordic countries - a research field in progress. Report from the Nordic research workshop on Green Care in Trondheim, June 2012. Accessed 11.1.2013:

http://www.regjeringen.no/upload/LMD/Vedlegg/Brosjyrer_veiledere_rapporter/Rapport_Green_care.pdf\#page=18

Bandura, A. 1997. Self-efficacy: The exercise of control. New York: Freeman.

Campbell, A., Converse, P., \& Rodgers, W. 1976. The quality of American life: perceptions, evaluations and satisfaction. New York: Sage Foundation.

Clayton, S. 2003. Environmental identity: a conceptual and an operational definition. In Clayton, S. \&. Opotow, S. (Eds.), Identity and the natural environment: the psychological significance of nature (pp. 45-65). London: The MIT Press.

Cervinka, R., Roderer K. \& Hefler, E. 2012. Are nature lovers happy? On various indicators of well-being and connectedness to nature. Journal of Health Psychology 17(3), 379-388.

Connor, K. M., \& Davidson, J. R. T. 2003. Development of a new resilience scale: the Connor-Davidson resilience scale (CD-RISC). Depression and Anxiety, 18(2), 76-82.

Det Kogelige Helse- og Omsorgsdepartment 2013. Rundskriv Nr. 1-7/2013, 3p. Acessed 1.12.2015: https:/www.regjeringen.no/contentassets/e779b918ee1547dbb778c3d4f5cb4b58/rundskrifi72013.pdf

Diener, E. 1984. Subjective well-being. Psychological Bulletin, 95, 542-575.

Dolan, P., Layard, R., \& Metcalfe, R. 2011. Measuring subjective well-being for public policy: recommendations on measures. Office for National Statistics. Retrieved November 13, 2012, from http://cep.lse.ac.uk/pubs/download/special/cepsp23.pdf

Eriksson, M., \& Lindström, B. 2006. Antonovsky's sense of coherence scale and the relation with health: a systematic review. Journal of Epidemiology and Community Health, 60(5), 376-38.

European Commission 2013. Directorate H. Sustainability and Quality of Agriculture and Rural Develop- 
ment H.3. Organic farming. Report on the results of the public consultation on the review of the EU policy on organic agriculture conducted by the directorate general for agriculture and rural development (15 January-10 April 2013). Brussels,19 September 2013. Accessed 1.12.2015: http://ec.europa.eu/agriculture/organic/documents/eupolicy/of-public-consultation-final-report_en.pdf.

Ewert, A., \& Yoshino, A. 2011. The influence of short-term adventure-based experiences on levels of resilience. Journal of Adventure Education \& Outdoor Learning, 1(1), 35-50.

Hofgemeinschaft Weide-Hardebek / LBF Gesellschaft mit beschränkter Haftung 2013: INCLUFAR project website. Accessed 1.12.2015: www.inclufar.eu.

Leck, C. 2013. The Impact of Care Farming in the UK, PhD Thesis 342 p, The University of Worcester. Accessed 1.12.2015:

http://www.carefarminguk.org/sites/carefarminguk.org/files/Leck\%20PhD\%20final\%20publish\%2009\%2013.pdf

Lundberg, O., \& Peck, M. 1995. A simplified way of measuring sense of coherence: experiences from a population survey in Sweden. The European Journal of Public Health, 5(1), 56-59.

Mansvelt, J. van, Lubbe M. van der 1999. Checklist for sustainable landscape management. Amsterdam: Elsevier. 181 p. ISBN 0444501592.

Olivos, P., \& Aragones, J. 2011. Psychometric properties of the environmental identity scale (EID). Psyecology, 2(1), 65-74.

Parkinson, J. 2007. Establishing a core set of national, sustainable mental health indicators for adults in Scotland: final report. Glasgow: NHS Health Scotland.

Pedersen, I., Nordaunet, T., Martinsen, E., Berget, B., \& Braastad, B. 2011. Farm animal-assisted intervention: relationship between work and contact with farm animals and change in depression, anxiety, and selfefficacy among persons with clinical depression. Issues in Mental Health Nursing, 32(8), 493-500

Sempik, J. 2007. Researching social and therapeutic horticulture for people with mental ill-health: a study of methodology. Loughborough: Loughborough University.

Sempik, J., Hine, R., \& Wilcox, D. 2010. Green care: a conceptual framework. A report of the working group on the health benefits of green care. COST Action 866, green care in agriculture. Loughborough: Loughborough University.

Schäfer, W. \& Merckens, S. 2015. Transfer workshop documentation. In: ADAM Projects and Products Portal for Leonardo da Vinci. Acessed 1.12.2015: http://www.adam-europe.eu/prj/10805/prd/5/1/R4\%20Transfer documentation.pdf

Scholz, U., Dona, B., Sud, S., \& Schwarzer, R. 2002. Is general self-efficacy a universal construct? Psychometric findings from 25 countries. European Journal of Psychological Assessment, 18(3), 242-251.

Schwarzer, R. (Ed.) 1992. Self-efficacy: thought control of action. Washington DC: Hemisphere.

Schwarzer, R., \& Jerusalem, M. 1995. Generalized Self-Efficacy Scale. In J. Weinman, S. Wright \& M. Johnston (Eds.), Measures in health psychology: a user's portfolio. Causal and control beliefs (pp. 35-37). Windsor, England: Nfer-Nelson.

Schweitzer, A. 1931. Aus meinem Leben und Denken. Leipzig, Felix Meiner, 211 p.

Stewart-Brown, S., Tennant, A., Tennant, R., Platt, S., Parkinson, J., \& Weich, S. 2009. Internal construct validity of the Warwick-Edinburgh mental well-being scale (WEMWBS): a Rasch analysis using data from the Scottish health education population survey. Health and Quality of Life Outcomes, 7(1), 15-23.

Stiftung Wege zur Qualität 2006. The Ways to Quality procedure. Accessed 1.12.2015: http://www.wegezurqualitaet.info/home.

Tennant, R., Hiller, L., Fishwick, R., Platt, S., Joseph, S., Weich, S. et al. 2007. The Warwick-Edinburgh mental well-being scale (WEMWBS): development and UK validation. Health and Quality of Life Outcomes, 5(1), 63. Retrieved May 1, 2011 from http://www.hqlo.com/content/pdf/1477-7525-5-63.pdf

United Nations 2006. Annex 1, Final report of the Ad Hoc Committee on a Comprehensive and Integral International Convention on the Protection and Promotion of the Rights and Dignity of Persons with Disabilities. A/61/611, 06-64530 (E) 081206, 33p. Accessed 1.12.2015: http://daccess-ddsny.un.org/doc/UNDOC/LTD/N06/645/30/PDF/N0664530.pdf?OpenElement

Vaishnavi, S., Connor, K., \& Davidson, J. 2007. An abbreviated version of the Connor-Davidson resilience scale (CD-RISC), the CD-RISC2: psychometric properties and applications in psychopharmacological trials. Psychiatry Research, 152(2-3), 293-297.

Waldron, S. 2010. Measuring subjective wellbeing in the UK. London: ONS.

von Weizsäcker, C. 1978. Die Bodelschwingh -Tradition. In: Deutlichkeit, Beiträge zu politischen und religiösen Gegenwartsfragen. Hanser Verlag, S 115-136. 